\title{
Implementasi Asas-Asas Umum Pemerintahan Yang Baik Pada Pemerintahan Kabupaten Dompu
}

\author{
Khalid Prawiranegara \\ Magister Hukum Fakultas Hukum Universitas Islam Indonesia Yogyakarta Indonesia \\ Jln. Cik Di Tiro No. 1 Yogyakarta Indonesia \\ 19912058@students.uii.ac.id
}

\begin{abstract}
The purpose of this study is to determine the implementation of the General Principles of Good Governance (AAUPB) in the Dompu Regency government and to examine the inhibiting factors in implementing AAUPB in the Dompu Regency government. This research is normative, the approach taken includes a statutory approach. The data collected were analyzed descriptively qualitatively. The results of the study conclude that, first, the administration of the Dompu Regency Government has implemented AAUPB as a guideline in the preparation of licensing policies in Dompu Regency, as stated in the Regent's Regulation Number 140 of 2010 concerning the Implementation of Environmental Document Services. Second, the inhibiting factor in the administration of the Dompu Regency Government is the quality factor of the human resources of the State Civil Apparatus in particular, namely the lack of understanding of technology.
\end{abstract}

Key Words: Dompu regency government; general principles of good governance

\begin{abstract}
Abstrak
Tujuan penelitian ini adalah untuk mengetahui implementasi Asas-Asas Umum Pemerintahan yang Baik (AAUPB) pada pemerintahan Kabupaten Dompu dan mengkaji faktor penghambat dalam menerapkan AAUPB pada pemerintahan Kabupaten Dompu. Penelitian ini bersifat normatif, pendekatan yang dilakukan meliputi pendekatan perundang-undangan. Data yang terkumpul dianalisis secara deskriptif kualitatif. Hasil penelitian menyimpulkan bahwa, pertama, penyelenggaraan Pemerintahan Kabupaten Dompu telah menerapkan AAUPB sebagai pedoman dalam penyusunan kebijakan perizinan di Kabupaten Dompu, dituangkan dalam Peraturan Bupati Nomor 140 Tahun 2010 tentang Penyelenggaraan Pelayanan Dokumen Lingkungan. Kedua, faktor penghambat dalam penyelenggaraan Pemerintahan Kabupaten Dompu adalah faktor kualitas sumber daya manusia Aparatus Sipil Negara secara lebih khusus yakni kurangnya pemahaman teknologi.
\end{abstract}

Kata-kata Kunci: Asas-asas umum pemerintahan yang baik; pemerintahan kabupaten Dompu 


\section{Pendahuluan}

Pemerintah dalam rangka mewujudkan tata pemerintahan yang baik, bersih dan berwibawa, dihadapkan pada pelaksanaan tugas yang sangat luas dan kompleks dalam upaya mensejahterakan rakyat. Pemikiran tentang kesejahteraan rakyat sebenarnya sudah ada sejak terbentuknya Negara Kesatuan Republik Indonesia. Pembukaan Undang-Undang Dasar Negara Republik Indonesia Tahun 1945 mengamanatkan bahwa tujuan didirikan Negara Republik Indonesia antara lain adalah memajukan kesejahteraan umum dan mencerdaskan kehidupan bangsa. ${ }^{1}$ Dengan berlakunya Undang-Undang Nomor 23 Tahun 2014 tentang Pemerintah Daerah, Pemerintah Daerah diberikan kewenangan untuk mengatur dan mengurus sendiri urusan pemerintahan menurut asas otonomi dan tugas pembantuan. Pemberian otonomi luas kepada daerah diarahkan untuk mempercepat terwujudnya kesejahteraan masyarakat melalui peningkatan pelayanan, pemberdayaan dan peranserta masyarakat. Pada dasarnya penyelenggaraan pemerintahan mengemban tiga fungsi hakiki, yaitu pelayanan (service), pemberdayaan (empowerment), dan pembangunan (development). Jadi selain melaksanakan pembangunan, pemerintah juga memberikan pelayanan publik. Perizinan mempunyai peranan vital, karena selain sebagai sumber PAD, perizinan juga sebagai instrumen perlindungan hukum atas kepemilikan atau penyelenggaraan kegiatan. izin merupakan suatu persetujuan dari penguasa berdasarkan undang-undang atau peraturan pemerintah, untuk dalam keadaan tertentu menyimpang dari ketentuan-ketentuan larangan perundangan".Izin dalam arti luas berarti persetujuan dari penguasa berdasarkan peraturan perundang-undangan untuk memperbolehkan melakukan tindakan atau perbuatan tertentu yang secara umum dilarang. ${ }^{2}$

Di sisi lain, birokrasi atau Penyelenggara negara mempunyai peranan yang sangat menentukan dalam penyelenggaraan negara untuk mencapai cita-cita perjuangan bangsa mewujudkan masyarakat yang adil dan makmur sebagaimana yang termaktub dalam Undang-Undang Dasar Republik Indonesia 1945 (selanjutnya disingkat UUD 1945). Penyelenggara negara adalah pejabat negara yang menjalankan fungsi eksekutif, legislatif, atau yudikatif, dan pejabat lain yang fungsi dan tugas pokoknya berkaitan dengan ketentuan peraturan perundang-undangan yang berlaku. Peran pemerintah selaku penyelenggara negara pada negara kesejahteraan sangat sentral karena diberi tugas untuk menyelenggarakan kesejahteraan rakyat. Oleh karena itu, kepada pemerintah

${ }^{1}$ Alinea keempat Undang-Undang Dasar Negara Republik Indonesia Tahun 1945.

${ }^{2}$ Lalu Dhedi Kusmana, Penerapan Asas-Asas Umum Pemerintahan Yang Baik Dalam Penerbitan Izin Di Kabupaten Lombok Timur, Jurnal Kajian Hukum dan Ius Vol I.Nomor 3 Tahun 2013, hlm. 576. 
diberikan kewenangan untuk turut campur dalam segala aspek kehidupan bermasyarakat. Dengan kewajiban tersebut yang dibebankan di pundak pemerintah, pemerintah dituntut untuk terlibat secara aktif dalam dinamika kehidupan masyarakat. ${ }^{3}$

Mewujudkan penyelenggara negara yang mampu menjalankan fungsi dan tugasnya secara sungguh-sungguh dan penuh tanggung jawab perlu adanya asasasas umum penyelenggaraan negara agar dapat tercipta tata kelola pemerintahan yang baik. Penyelenggara negara yang bersih merupakan penyelenggara negara yang menaati asas-asas umum penyelenggaraan negara dan bebas dari praktek korupsi, kolusi, dan nepotisme (KKN), serta perbuatan tercela lainnya. Apabila penyelenggara negara bertindak bebas tanpa harus terikat secara sepenuhnya kepada undang-undang maka akan membuka peluang bagi penyalahgunaan kewenangan. Penyalahgunaan kewenangan akan membuka kemungkinan benturan kepentingan antara penyelenggara negara dengan rakyat yang merasa dirugikan akibat penyalahgunaan kewenangan tersebut. Sehingga di dalam penyelenggaraan negara membutuhkan adanya pembatasan kekuasaan pemerintah atau negara dengan tujuan untuk memberikan perlindungan terhadap hak-hak individu. Tidak ada kekuasaan negara yang boleh dibiarkan bebas tanpa adanya pembatasan dan pengawasan. Sehingga diperlukan adanya berbagai macam cara, prosedur, asas, atau sistem yang dikembangkan dalam berbagai sistem ketatanegaraan. Sistem pembatasan kekuasaan, asas legalitas, mekanisme hak uji materi, ataupun peradilan administrasi negara merupakan contoh berbagai asas, sistem atau prosedur pembatasan kekuasaan negara yang dimaksud. Untuk menilai apakah tindakan pemerintah sejalan dengan asas negara hukum atau tidak, dapat menggunakan asas-asas umum pemerintahan yang baik. ${ }^{4}$

Asas-asas umum pemerintahan yang baik (selanjutnya disebut AAUPB) lahir dari praktik penyelenggaraan negara dan pemerintahan sehingga bukan produk formal suatu lembaga negara seperti undang-undang. Asas-asas umum pemerintahan yang baik dapat dipahami sebagai asas-asas umum yang dijadikan sebagai dasar dan tata cara dalam penyelenggaraan pemerintahan yang layak, yang dengan cara demikian penyelenggaraan pemerintahan itu menjadi baik, sopan, adil, dan terhormat, bebas dari kezaliman, pelanggaran peraturan, tindakan penyalahgunaan wewenang dan tindakan sewenang-wenang. Mendasarkan pada pendapat Jazim Hamidi bahwa: pertama, AAUPL merupakan

${ }^{3}$ Agustin Widjiastuti, Peran AAUPB Dalam Mewujudkan Penyelenggaraan Pemerintahan Yang Bersih Dan Bebas Dari KKN, Jurnal Perspektif, Volume 22. Nomor 22 Tahun 2017, hlm. 116.

${ }^{4}$ Ibid. 
nilai-nilai etik yang hidup dan berkembang dalam lingkungan Hukum Administrasi Negara, dan berfungsi sebagai pegangan bagi para pejabat administrasi negara dalam menjalankan fungsinya, merupakan alat uji bagi hakim administrasi dalam menilai tindakan administrasi negara (yang berwujud penetapan atau beschikking) dan sebagai dasar pengajuan gugatan bagi pihak penggugat. Kedua, sebagian besar dari AAUPB masih merupakan asas-asas yang tidak tertulis, masih abstrak, dan dapat digali dalam praktik kehidupan di masyarakat, dan sebagian asas yang lain sudah menjadi kaidah hukum tertulis dan terpencar dalam berbagai peraturan hukum positif. ${ }^{5}$ Konsepsi AAUPB menurut Crince Le Roy yang meliputi: asas kepastian hukum, asas keseimbangan, asas bertindak cermat, asas motivasi untuk setiap keputusan badan pemerintah, asas tidak boleh mencampuradukkan kewenangan, asas kesamaan dalam pengambilan keputusan, asas permainan yang layak, asas keadilan atau kewajaran, asas menanggapi pengharapan yang wajar, asas meniadakan akibatakibat suatu keputusan yang batal, dan asas perlindungan atas pandangan hidup pribadi. Koentjoro menambahkan dua asas lagi, yakni: asas kebijaksanaan dan asas penyelenggaraan kepentingan umum.

Adanya penerapan asas-asas umum pemerintahan yang baik merupakan konsekuensi yang logis dari bagi setiap daerah. Esensi pemerintah daerah berkaitan dengan kewenangan yang dimiliki dalam mengurus dan mengatur urusan rumah tangga pemerintahannya. Kewenangan pemerintahan daerah tersebut akan berhubungan dengan pola pembagian kekuasaan dalam penyelengaraan pemerintahan yang mengacu dalam sistem pemerintahan Negara Kesatuan Republik Indonesia. Ketentuan yang menyangkut tentang pemerintahan daerah telah diakomodasikan dalam Pasal 18 UUD NRI tahun 1945 beserta penjelasannya. Di dalamnya mengakui adanya keragaman dan hak asalusul yang merupakan bagian dari sejarah panjang bangsa Indonesia. ${ }^{6}$

Kabupaten Dompu merupakan salah satu kabupaten di Provinsi NTB, kabupaten Dompu terletak di pulau sumbawa NTB, Dompu yang dulunya di kenal sebagai kota kerajaan dan kini sudah menjadi kabupaten dompu atau daerah dompu. Dompu adalah sebuah daerah kecil yang begitu kaya dengan tempat wisata, baik itu wisata kuliner maupun wisata alam seperti gunung, pantai, dll, yang perlu dikembangkan dan dilestarikan. Dompu memang memiliki kekayaan wisata yang begitu banyak, namun tempat wisata yang berada di daerah Dompu masih banyak yang belum diketahui oleh para wisatawan yang berdomisisli di luar daerah dompu di karenakan tempat wisata yang berada di

\footnotetext{
${ }^{5}$ Ibid.

${ }^{6}$ Sirojul Munir, Hukum Pemerintah Daerah di Indonesia, Genta Publishing, Yogyakarta, 2013, hlm. 94-95.
} 
daerah Dompu belum terekspos sehingga sebagian besar wisatawan yang berada di luar daerah Dompu atau di seluruh Indonesia belum mengetaui hal itu. Untuk itu pemanfaatan informasi wisata sangat membantu para wisatawan yang ingin berkunjung di beberapa tempat wisata yang berada di daerah Dompu.

\section{Rumusan Masalah}

Berdasarkan latar belakang sebagaimana telah diuraikan sebelumnya, maka rumusan masalah dalam penelitian ini yaitu: pertama, bagaimana implementasi Asas-Asas Umum Pemerintahan yang Baik (AAUPB) pada pemerintahan Kabupaten Dompu? Kedua, apa yang menjadi faktor penghambat dalam menerapkan Asas-Asas Umum Pemerintahan yang Baik (AAUPB) pada pemerintahan Kabupaten Dompu?

\section{Tujuan Penelitian}

Penelitian ini bertujuan untuk mengetahui, pertama, implementasi Asas-Asas Umum Pemerintahan yang Baik (AAUPB) pada pemerintahan Kabupaten Dompu dan mengkaji faktor penghambat dalam menerapkan Asas-Asas Umum Pemerintahan yang Baik (AAUPB) pada pemerintahan Kabupaten Dompu.

\section{Metode Penelitian}

Penelitian ini termasuk ke dalam penelitian normatif dengan pendekatan pendekatan perundang-perundangan. Jenis data yang dibutuhkan adalah data kualitatif yang bersumber dari data primer $^{7}$ dan sekunder. ${ }^{8}$ Oleh karena itu, instrumen utama untuk mendapatkan data dan mengumpulkan data penelitian adalah peneliti sendiri. ${ }^{9}$ Data yang diperoleh dari hasil penelitian kepustakaan dianalis secara deskriptif kualitatif, sehingga mampu menjawab seluruh permasalahan yang ada. Data yang terkumpul dalam penelitian ini dimungkinkan terdapat kelemahan. Untuk mengatasi hal tersebut yakni agar data tetap terjamin validasi (kesasihan). Objektivitas dan kendalanya ditempuh teknik pemeriksaan triangulasi. ${ }^{10}$ Dalam penelitian ini digunakan triangulasi sumber dan metode. Triangulasi sumber dan metode dilakukan dengan cara melakukan cek silang antara sumber data dan metode yang satu dengan yang lainnya, baik

\footnotetext{
${ }^{7}$ Peter Mahmud Marzuki, Metode Penelitian Hukum, Kencana Prenada Media Grup, Surabaya, 2005, hlm. 181.

8 Ibid

9 Sudarwan Danim, Menjadi Peneliti Kualitatif, Ancangan Metodelogi, Presentasi Dan Publikasi Penelitian untuk Mahasiswa dan Peneliti Pemula Bidang Ilmu - Ilmu Social, Pendidikan Dan Humaniora, Pustaka Setia, Bandung, 2020, hlm. 37

${ }^{10}$ Ibid.
} 
yang diperoleh lewat metode wawancara, observasi, studi dokumentasi/pustaka maupun catatan lapangan.

\section{Hasil Penelitian dan Pembahasan}

Sejak Orde Baru jatuh dan dilakukan amendemen terhadap UUD 1945 berimplikasi luas terhadap semua bangunan negara termasuk pada tatanan pemerintahan pusat dan pemerintahan di daerah. Pemerintahan tidak lagi bersifat sentralistis, melainkan bersifat desentralisasi dan kepada daerah diberikan hak untuk melaksanakan otonomi daerah yang seluas-luasnya. Setelah memasuki era tersebut sampai saat ini, eksistensi peraturan daerah (dan produk hukum daerah lainnya) menjadi isu sentral. Dalam rangka melaksanakan otonomi daerah, kepada daerah kabupaten/kota diberikan kewenangan yang luas dan menjadi ujung tombak dalam pelaksanaan pelayanan publik. Oleh karena itu, alat administrasi negara di daerah dituntut supaya dapat menjalankan tugas dan kewajibannya secara baik dan profesional, agar tidak merugikan warga masyarakat yang dilayaninya. Hal ini dikarenakan pelayanan kepada masyarakat termasuk di dalamnya layanan perizinan investasi menjadi tugas pokok pemerintah di dalam negara hukum modern (welfare state). Untuk dapat melaksanakan tugasnya secara baik dan profesional tersebut diperlukan perangkat dalam bentuk produk hukum daerah yang di dalamnya telah merumuskan dan mengimplementasikan asas-asas umum pemerintahan yang baik (AAUPB). Pemikiran tentang perlunya AAUPB ini telah lama digagas oleh para ahli Hukum Administrasi Negara.

Utrecht mengemukakan bahwa perkembangan tugas dan tanggungjawab pemerintah dalam negara modern inilah yang kemudian memunculkan pemikiran tentang adanya asas-asas umum pemerintahan yang baik yang harus diperhatikan oleh alat administrasi negara, apalagi kepada mereka juga diberikan wewenang berdasarkan diskresi atau Ermessen (bahasa Jerman), yaitu suatu tindakan atas inisiatif sendiri untuk menyelesaikan persoalan-persoalan penting yang mendesak yang muncul secara tiba-tiba di mana hukum tertulis tidak mengaturnya dan serta harus dapat dipertanggungjawabkan secara hukum dan moral. ${ }^{11}$

Di dalam negara hukum modern termasuk negara Indonesia, AAUPB diperlukan sebagai pedoman dan arahan bagi alat administrasi negara untuk mencapai tujuan negara. AAUPB yang awalnya merupakan nilai-nilai etik yang telah berkembang dalam masyarakat tersebut harus dipatuhi oleh aparat

${ }^{11}$ Eny Kusdarini, "Asas-Asas Umum Pemerintahan Yang Baik Pada Produk Hukum Perizinan Investasi Pemerintah Daerah”, Jurnal Hukum Ius Quia Iustum No. 4 Vol. 24 Oktober 2017, hlm. 664. 
pemerintah pusat dan pemerintah daerah Asas-asas tersebut diperlukan agar tindakan yang dilakukan oleh alat administrasi negara tidak merugikan warga negara. SF. Marbun mengemukakan, bahwa di dalam sebuah negara hukum, pasti mengalami berbagai persoalan yang berkaitan dengan penyelenggaraan negara, utamanya untuk mencapai tujuan negara. Hal ini dapat dihindari apabila penyelenggara negara yang dalam hal ini diwakili oleh pejabat tata usaha negara dalam menjalankan tugas dan kewenangannya mengindahkan aturan hukum dan AAUPB sesuai dengan prinsip-prinsip negara hukum dan tidak melanggar hak asasi warga negara. AAUPB merupakan nilai etik yang berkembang dalam hukum administrasi negara yang berfungsi untuk mencegah perselisihan kepentingan antara badan atau pejabat tata usaha negara dan dipakai sebagai pedoman bagi badan atau pejabat tata usaha negara dalam mengeluarkan suatu penetapan/keputusan (beschikking). ${ }^{12}$

Henk Addink menyatakan, bahwa ada tiga landasan utama dalam negara hukum modern, yakni: the rule of law (penegakan hukum), democrazy (demokrasi), dan good governance (tata pemerintahan yang baik). Tata pemerintahan yang baik merupakan kepatutan dari penguasa negara secara transparans dan partisipatif, bahkan lebih dari itu. Pada hakekatnya pemerintahan yang baik ini berkenaan dengan pemenuhan tiga tugas dasar pemerintahan, yaitu untuk menjamin keamanan seseorang dan masyarakat, mengatur kerangka kerja yang efektif dan bertanggungjawab untuk sektor publik, dan mendukung tujuan ekonomi dan sosial negara sesuai harapan-harapan penduduk. ${ }^{13}$

\section{Asas-Asas Umum Pemerintahan yang Baik (AAUPB)}

Selain asas legalitas dalam melakukan penyelenggaraan Negara harus mengindahkan asas-asas yang berlaku dalam Hukum Administrasi Negara, salah satunya adalah Asas-asas Umum Pemerintahan yang Baik (AAUPB) sebagai dasar penyelenggaraan Negara yang bebas dari Korupsi, Kolusi dan Nepotisme. Sejak diterapkannya konsep negara (welfare state) yang menempatkan pemerintah sebagai pihak yang bertanggungjawab terhadap kesejahteraan umum warga negaranya, untuk mewujudkan kesejahteraan ini pemerintah diberi wewenang untuk campur tangan dalam segala lapangan kehidupan masyarakat yang dalam keadaan tertentu dapat bertindak tanpa berdasarkan pada peraturan perundangundangan tetapi berdasarkan inisiatif. Untuk menghindari tindakan 
pemerintah/pejabat sendiri dalam membuat kebijakan dalam melaksanakan fungsinya sebagai penyelenggara negara. ${ }^{14}$

Pada 2014 DPR-RI selaku badan legislatif mengesahkan Undang-Undang Nomor 30 Tahun 2014 tentang Administrasi Negara dimana dalam Pasal 5 dinyatakan bahwa AAUPB merupakan asas dari penyelenggaraan Negara kemudian pada Pasal 6 dan Pasal 8 ditegaskan bahwa dalam melaksanakan kewenangannya pejabat Pemerintah berdasarkan AAUPB. Bahkan pada Pasal 7 ditegaskan lagi bahwa pejabat pemerintahan berkewajiban mematuhi AAUPB dan dalam penyelenggaraan negara wajib sesuai AAUPB. Secara terperinci ada 8 asas yang dimasukan dalam Pasal 10 Undang-Undang Nomor 30 tentang Administrasi Pemerintahan. ${ }^{15}$ (1) Kepastian hukum; (2) Kemanfaatan; (3) Ketidakberpihakan; (4) Kecermatan; (5) Tidak menyalahgunakan wewenang; (6) Keterbukaan; (7) Kepentingan umum; dan (8) Pelayanan yang baik. Namun Undang-Undang Administrasi Negara ini tetap terbuka bagi AAUPB lainnya diluar yang disebutkan pada Pasal 10 Undang-Undang Nomor 30 Tahun 2014 dengan syarat sepanjang AAUPB dijadikan dasar penilaian oleh hakim dan tertuang dalam putusan pengadilan yang berkekuatan hukum tetap. ${ }^{16}$

\section{Implementasi Asas-Asas Umum Pemerintahan yang Baik pada Kabupaten Dompu}

Implementasi Asas-Asas Umum Pemerintahan yang Baik (AAUPB) di pemerintah daerah dilakukan disemua sektor, terkhusus di sektor pelayanan. Dalam penyelenggaraan pemerintah terkait dengan hal Asas-Asas Umum Pemerintahan yang Baik (AAUPB) dapat dilihat dalam Pasal 58 Undang-Undang 23 Tahun 2014 tentang Pemerintah Daerah yang menetapkan: "dalam menyelenggarakan Pemerintahan Daerah berpedoman pada asas penyelenggaraan pemerintahan negara yang terdiri atas: a. kepastian hukum; b. tertib penyelenggara negara; $c$. kepentingan umum; d. keterbukaan; e. proporsionalitas; f. profesionalitas; g. akuntabilitas; h. efisiensi; i. efektivitas; dan j. Keadilan. ${ }^{17}$

Tata pemerintahan yang baik yang diwujudkan dalam Asas-Asas Umum Pemerintahan yang Baik (AAUPB) juga diperlukan dalam penyusunan kebijakan layanan perizinan investasi pemerintah daerah kabupaten/kota di Indonesia, utamanya di kabupaten Dompu. Asas-asas tersebut diperlukan sebagai pedoman dan arahan bagi aparat pemerintah daerah yang ada di NTB dalam mengeluarkan

${ }^{14}$ Ridwan HR, Hukum Administrasi Negara, PT. RajaGrafindo, Jakarta, 2016, hlm. 244

15 Undang - Undang Nomor 30 Tahun 2014 tentang Administrasi Pemerintahan.

16 S.F. Marbun, Asas-asas Umum Penyelenggaraan Pemerintahan Yang Layak, Cetakan Pertama, FH UII Press, Yogyakarta, 2014, hlm. 60

17 Pasal 58 Undang-Undang Nomor 23 Tahun 2014 tentang Pemerintahan Daerah 
perizinan investasi yang dilakukan sesuai dengan koridor hukum. Pengaturan kebijakan perizinan investasi yang memerlukan rumusan dan implementasi AsasAsas Umum Pemerintahan yang Baik (AAUPB) di daerah misalnya dalam hal Izin Usaha Industri, Izin Usaha Perdagangan, Izin Gangguan (HO), Izin Mendirikan Bangunan, dan pengaturan yang terkait dengan layanan perizinan investasi lainnya. Namun demikian, diduga belum banyak produk hukum daerah termasuk di NTB yang telah merumuskan dan mengimplementasikan Asas-Asas Umum Pemerintahan yang Baik (AAUPB) di dalamnya. Asas-Asas Umum Pemerintahan yang Baik (AAUPB) ini awalnya merupakan norma hukum tidak tertulis yang dipakai sebagai dasar/standar bagi badan-badan administratif yang dikombinasikan dengan hukum tertulis dalam menjalankan wewenangnya. ${ }^{18}$

Selain itu asas-asas tersebut juga bisa dipakai oleh warga negara yang ingin menuntut apabila tindakan-tindakan aparat administrasi merugikan warga. AAUPB diperlukan juga dalam perumusan kebijakan perizinan investasi di daerah. Apabila pengaturan dalam bentuk produk-produk hukum daerah seperti peraturan daerah, peraturan bupati/walikota, surat keputusan bupati/walikota dan peraturan kebijaksanaan (beleidsregel) daerah di bidang perizinan investasi itu tidak dilakukan dengan hati-hati dan bijaksana sesuai dengan AAUPB, maka akan dapat merugikan bagi masyarakat yang terkena dampak akibat pemberian izin usaha yang tidak dilakukan dengan bijaksana dan mengindahkan asas kehatihatian serta asas-asas umum pemerintahan yang baik lainnya. AAUPB merupakan asas-asas/prinsip-prinsip hukum, di samping itu juga merupakan asas- asas/prinsip-prinsip kebijakan. Oleh karena itu, pengaturan kebijakan perizinan investasi di daerah juga harus mengimplementasikan asas-asas umum pemerintahan yang baik, mengingat bahwa perizinan merupakan instrumen penting bagi pemerintah daerah untuk mengendalikan kegiatan di daerah supaya tidak merugikan masyarakat di daerah. ${ }^{19}$

Perkembangan konsep ini terkait dengan tuntutan adanya tata kelola pemerintahan yang baik, yang tidak hanya dilaksanakan oleh pemerintah pusat saja, namun juga harus dilaksanakan oleh aparat pemerintah di daerah. Bahkan pada saat ini pelaksanaan tata kelola pemerintahan yang baik juga melibatkan pihak swasta. Contoh konsep AAUPB yang telah dituangkan dalam peraturan perundang-undangan di tingkat daerah yakni Peraturan Daerah Kabupaten Dompu Nomor 6 Tahun 2012 tentang Penyelenggaraan Kepariwisataan. Konsep AAUPB sudah dirumuskan secara eksplisit dalam beberapa pasal peraturan daerah tersebut seperti asas kepentingan umum, asas keseimbangan hak dan

${ }^{18}$ Eny Kusdarini, Asas-Asas Umum Pemerintahan Yang Baik, UNY Press, Yogyakarta, 2019, hlm. 666.

${ }^{19}$ Ibid. 
kewajiban dan asas keprofesionalan, di samping itu juga secara eksplisit konsep AAUPB telah dituangkan dalam Peraturan Bupati (Perbup) Nomor 140 Tahun 2010 tentang Penyelenggaraan Pelayanan Dokumen Lingkungan. Perbup tersebut telah mencantumkan dan menguraikan konsep AAUPB di dalamnya seperti asas kepastian hukum, asas keterbukaan, asas akuntabilitas dan asas efisiensi. Asasasas umum pemerintahan yang baik ini mengikat dan menjadi pedoman aparat perintah di lingkungan pemerintah Kabupaten Dompu di dalam menjalankan tugasnya untuk melakukan pelayanan publik di wilayahnya. ${ }^{20}$

Seperti yang penulis sampaikan diatas bahwa pelaksaan AAUPB sendiri di bisa dilihat dalam penyusunan kebijakan layanan perizinan investasi pemerintah daerah kabupaten/kota di Indonesia, utamanya di Kabupaten Dompu. Asas-asas tersebut diperlukan sebagai pedoman dan arahan bagi aparat pemerintah daerah yang ada di Kabupaten Dompu dalam mengeluarkan perizinan investasi yang dilakukan sesuai dengan koridor hukum. Pengaturan kebijakan perizinan investasi yang memerlukan rumusan dan implementasi AAUPB di daerah misalnya dalam hal Izin Usaha Industri, Izin Usaha Perdagangan, Izin Gangguan (HO), Izin Mendirikan Bangunan, dan pengaturan yang terkait dengan layanan perizinan investasi lainnya. Namun demikian, diduga belum banyak produk hukum daerah termasuk di Kabupaten Dompu yang telah merumuskan dan mengimplementasikan AAUPB di dalamnya. AAUPB ini awalnya merupakan norma hukum tidak tertulis yang dipakai sebagai dasar/standar bagi badanbadan administratif yang dikombinasikan dengan hukum tertulis dalam menjalankan wewenangnya. Selain itu asas-asas tersebut juga bisa dipakai oleh warga negara yang ingin menuntut apabila tindakan-tindakan aparat administrasi merugikan warga.

Mengutip pendapat Ten Berge, Tatiek Sri Djatmiati mengemukakan bahwa motivasi dalam penggunaan sistem izin adalah: ${ }^{21}$ (a) keinginan untuk mengarahkan (mengendalikan) aktivitas-aktivitas tertentu, misalnya izin bangunan; (b) mencegah bahaya bagi lingkungan (izin-izin lingkungan); (c) keinginan untuk melindungi obyek-obyek tertentu (izin tebang, izin membongkar pada monumen-monumen); (d) hendak membagi benda-beda yang jumlahnya sedikit (izin penghunian daerah pada penduduk) dan; (e) pengarahan dengan menyeleksi orang-orang dan aktivitas-aktivitas (izin berdasarkan Drank-en Horecawet, yang mana pengurus harus memenuhi persyaratan tertentu". Oleh sebab itu implementasi AAUPB dalam pemerintahan Kabupaten Dompu bisa dilihat telah dijalankan dengan baik, sebab AAUPB ini sendiri telah dijadikan

\footnotetext{
${ }^{20}$ Ibid.

${ }^{21}$ Ibid., hlm. 667
} 
landasan oleh pemerintah Kabupaten Dompu sebagai pedoman dalam penyusunan kebijakan perizinan di Kabupaten Dompu, lebih khususnya juga penerapan AAUPB ini juga kemudian ditafsirkan kembali oleh Pemerintah Kabupaten Dompu dengan dituangkan dalam Peraturan Bupati Nomor 140 Tahun 2010 tentang Penyelenggaraan Pelayanan Dokumen Lingkungan. Peraturan Bupati tersebut telah mencantumkan dan menguraikan konsep AAUPB di dalamnya seperti asas kepastian hukum, asas keterbukaan, asas akuntabilitas dan asas efisiensi. Asas-asas umum pemerintahan yang baik ini mengikat dan menjadi pedoman aparat perintah di lingkungan pemerintah Kabupaten Dompu di dalam menjalankan tugasnya untuk melakukan pelayanan publik di wilayahnya.

Sejauh ini menurut penulis pelaksanaan AAUPB di Kabupaten Dompu sudah cukup baik, karena dalam hal pelayanan khususnya dalam pengurusan izin pemerintah Kabupaten Dompu sudah menerapkan semua AAUPB yang ada, hal tersebut dapat dilihat dari inovasi yang dilakukan oleh pemerintah Kabupaten Dompu khususnya Dinas Penanaman Modal dan Pelayanan Terpadu Satu Pintu Kabupaten Dompu yang telah menggunakan layanan online dalam hal pengurusan perizinan. Pelayanan online ini selain meningkatkan efisiensi pengurusan dimana masyarakat tidak perlu melakukan pengantrian lagi dalam hal mengurus perizinan, juga masyarakat dapat secara langsung memantau terkait dengan status perizinan yang dimohonkan, dalam hal ini pelayanan online ini secara langsung maupun tidak langsung telah memenuhi asas keterbukaan, asas akuntabilitas yang ada dalam AAUPB.

\section{Faktor Penghambat dalam Menerapkan Asas-asas Umum Pemerintahan yang Baik (AAUPB) pada Pemerintahan Kabupaten Dompu}

Instansi pemerintah sebagai penyelenggara adrninistrasi publik dan individu atau masyarakat penerima layanan publik. Undang-Undang Nomor 30 Tahun 2014 tentang Adminitrasi Pemerintahan sangat dibutuhkan oleh Indonesia pada saat ini atas dasar beberapa alasan dibawah ini. ${ }^{22}$ Tidak terkecuali pemerintah Kabupaten Dompu, sebagai salah satu pemerintah daerah yang mempunyai kewenangan yang sangat besar dalam mengurusi rumah tangganya sendiri. Jimly berpendapat, bahwa dalam paham negara hukum segala tindakan pemerintahan harus didasarkan atas peraturan perundang-undangan yang sah dan tertulis. Peraturan perundang-undangan tertulis tersebut harus ada dan berlaku lebih dulu atau mendahului tindakan atau perbuatan administrasi yang dilakukan. Dengan demikian, setiap perbuatan atau tindakan administrasi harus didasarkan atas aturan atau rules and procedures" (regels). 
Fungsi asas-asas umum pemerintahan yang baik dalam penyelenggaraan pemerintahan adalah sebagai pedoman atau penuntun bagi pemerintah atau pejabat administrasi negara dalam rangka pemerintahan yang baik. Dalam hubungan ini, Muin Fahmal mengemukakan bahwa asas umum pemerintahan yang layak sesungguhnya adalah rambu-rambu bagi para penyelenggara negara dalam menjalankan tugasnya. Rambu-rambu tersebut diperlukan agar tindakantindakan tetap sesuai dengan tujuan hukum yang sesungguhnya. AAUPB dapat diibaratkan sebagai rambu lalu lintas dan pedoman perjalanan dalam rangka memperlancar hubungan pemerintahan yaitu antara pemerintah dan yang diperintah atau warga masyarakat. AAUPB selanjutnya dijadikan sebagai dasar penilaian dan upaya administrasi, di samping sebagai norma hukum tidak tertulis bagi tindakan pemerintah.

Tentu tidak mudah bagi pemerintah Kabupaten Dompu dalam menerapkan AAUPB di lingkungan wilayah yang menjadi kewenangannya. Dalam implementasi AAUPB terdapat sejumlah faktor-faktor yang menjadi hambatan dalam pelaksanaan AAUPB. Adapun faktor-faktor tersebut adalah penjaringan aspirasi masyarakat yang tidak merata, biasanya yang diundang dalam jaring aspirasi bersifat elitis, kurangnya kesadaran masyarakat terhadap partisipasi mereka terhadap pembuatan kebijakan atau program-program Kemudian dalam penerapan transparansi, pemerintah kurang memberikan informasi yang dibutuhkan oleh masyarakat sehingga masyarakat tidak mengetahui sama sekali kebijakan maupun peraturan daerah yang akan dibuat pemerintah. Kalau penerapan akuntabilitas pemerintahan juga kurang melaksanakan pertanggungjawabannya kepada masyarakat, hal ini ditandai dengan Laporan Keterangan Pertanggungjawaban yang ditujukan kepada DPRD terkadang tidak sesuai dengan program-program yang sudah dilaksanakan.

Mengacu pada faktor-faktor penghambat dan pendukung suatu implementasi dalam lingkupan AAUPB terkait pelayanan public menunjukkan bahwa mengemukakan acuan faktor penghambat dan pendukung dimaksudkan agar pelayanan publik lebih akuntabel, transparan, jelas dalam kepastian hukum serta adil. Dalam implementasi AAUPB di Kabupaten Dompu sendiri, Kepala Dinas Penanaman Modal dan Pelayanan Terpadu Satu Pintu Kabupaten Dompu Lalu Gita Ariadi mengatakan terdapat faktor penghambat dalam mewujudkan tata kelola pemerintahan yang baik salah satunya terkait SDM Pegawai Negeri Sipilnya, walaupun mereka sangat antusias terhadap penyelenggaraan Pemerintahan tetapi dari segi kualitas masih rendah di tempat tersebut. Selain itu juga terkait dengan pemberian fasilitas dan penggunaan teknologi yang masih kurang memadai di setiap kantor. Hal ini tentu merupakan faktor penghambat 
dalam Penyelenggaraan Pemerintahan Kabupaten Dompu. Karena saat ini pendidikan dan teknologi sangat memperahi dalam mewujudkan suatu pembangunan baik itu sebuah negara, daerah maupun sebuah desa sekalipun. Oleh karena itu semakian baik nya SDM dan melek teknologi akan sangat membantu dalam upaya mewujudkan tata kelola pemerintahan daerah yang baik.

\section{Penutup}

Berdasarkan pembahasan sebagaimana diuraikan sebelumnya, maka penelitian ini menyimpulkan bahwa, pertama, implementasi AAUPB dalam pemerintahan Kabupaten Dompu telah dijalankan dengan baik, sebab sebagai pedoman dalam penyusunan kebijakan perizinan di Kabupaten Dompu, dengan dituangkan dalam Peraturan Bupati Nomor 140 Tahun 2010 tentang Penyelenggaraan Pelayanan Dokumen Lingkungan. Kedua, faktor penghambat dalam mewujudkan tata kelola pemerintahan yang baik salah satunya terkait SDM Pegawai Negeri Sipilnya, walaupun mereka sangat antusias terhadap penyelenggaraan Pemerintahan tetapi dari segi kualitas masih rendah di tempat tersebut. Selain itu juga terkait dengan pemberian fasilitas dan penggunaan teknologi yang masih kurang memadai di setiap kantor.

\section{Daftar Pusta}

\section{Buku}

Eny, Kusdarini, Asas-Asas Umum Pemerintahan Yang Baik, UNY Press, Yogyakarta, 2019.

Peter Mahmud, Marzuki, Metode Penelitian Hukum, Kencana Prenada Media Grup, Surabaya, 2005.

Ridwan, HR., Hukum Administrasi Negara, PT. RajaGrafindo, Jakarta, 2016.

S.F., Marbun, Asas - asas Umum Penyelenggaraan Pemerintahan Yang layak, Cetakan Pertama, FH UII Press, Yogyakarta, 2014.

Sirojul, Munir, Hukum Pemerintah Daerah di Indonesia, Genta Publishing, Yogyakarta, 2013.

Sudarwan, Danim, Menjadi Peneliti Kualitatif, Ancangan Metodelogi, Presentasi Dan Publikasi Penelitian untuk Mahasiswa dan Peneliti Pemula Bidang Ilmu - Ilmu Social, Pendidikan Dan Humaniora, Pustaka Setia, Bandung, 2020.

\section{Jurnal}

Lalu Dhedi Kusmana, Penerapan Asas-Asas Umum Pemerintahan Yang Baik Dalam Penerbitan Izin Di Kabupaten Lombok Timur, Jurnal Kajian Hukum dan Ius Vol I.Nomor 3 Tahun 2013.

Agustin Widjiastuti, Peran AAUPB Dalam Mewujudkan Penyelenggaraan Pemerintahan Yang Bersih Dan Bebas Dari KKN, Jurnal Perspektif, Volume 22. Nomor 22 Tahun 2017. 
Eny Kusdarini, Asas-Asas Umum Pemerintahan Yang Baik Pada Produk Hukum Perizinan Investasi Pemerintah Daerah, Jurrnal Ius Quia Iustum No. 4 Vol. 24 Oktober 2017.

\section{Peraturan Perundang-undangan}

Undang-Undang Dasar Negara Republik Indonesia Tahun 1945, Lembaran Negara Republik Indonesia Nomor 1, Tambahan Lembaran Negara Republik Indonesia Nomor 1.

Undang-Undang Nomor 30 Tahun 2014 tentang Administrasi Pemerintahan, Lembaran negara Republik Indonesia tahun 2014, Tambahan Lembaran Negara Republik Indonesia Nomor 5601.

Undang-Undang Nomor 23 Tahun 2014 tentang Pemerintah Daerah, Lembaran negara Republik Indonesia tahun 2014, Tambahan Lembaran Negara Republik Indonesia Nomor 5587. 